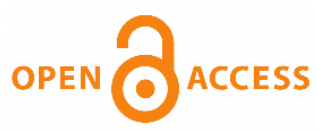

Authors' contribution:

A) conception and design of the study

B) acquisition of data

C) analysis and interpretation of data

D) manuscript preparation

E) obtaining funding

\title{
Life Skill Development and Transfer beyond Sport
}

\author{
Deborah Agnew $^{\text {A-E }}$, Kathryn Jackson ${ }^{\text {A,C,D }}$, Shane Pill ${ }^{\mathrm{C}-\mathrm{D}}$, \\ Christine Edwards ${ }^{\mathrm{D}}$
}

Flinders University, Australia

ABSTRACT

The aim of this research was to investigate the current life skills education programs offered by the Australian Football League (AFL) for elite footballers in order to determine the retention of life skill knowledge and transfer beyond sport. Life skill education in sport is an increasing phenomenon. Life skills sport programs are capable of delivering positive outcomes when nurtured through a deliberately designed curriculum and purposeful teaching strategies. However, it is not known how life skills are learned and importantly what the impact of life skills education on long term behavioural changes is. It is apparent from the literature that there is a need to identify how knowledge is acquired and importantly retained through life skills education programs. This was a qualitative research project from a life history perspective. Twenty footballers who had been delisted from an elite Australian football club and had subsequently returned to a South Australian state-based football club took part in semistructured interviews. The data was analysed through an inductive thematic analysis. Two themes emerged from the data: football related development and holistic development. It was clear that football clubs placed importance on the development of life skills that transfer beyond the sport. However, given the footballers in this research have not fully transferred into life after sport, their perception of the broader transferability of their life-skill development beyond sport is limited. This research concludes that the current format of life skill education (delivering content) that the players in this study were exposed to was not effective because the players failed to be able to make connections from the program to life outside of football. Therefore, the programs are unlikely to have any long-term benefit to player health and well-being during their post-elite football life.

KEYWORDS Australian football, Life-skills, Education, Life history, knowledge transfer

\section{Introduction}

This paper reports on the findings of a project investigating the life skills development of players occurring in the sport of Australian football from the perspective of the players. Life skills can be defined as the skills required to deal with the demand and challenges of everyday life (Holt, Tamminen, Tink \& Black, 2009). Effective life skills programs ensure transfer of knowledge and the development of positive behaviours such as assertiveness, self-awareness, decision making, communication, problem solving, and critical and innovative thinking (Nasheeda, Abdullah, Krauss \& Ahmed, 2018). Many of the existing programs are implemented based on the value of life skill components. Frequently programs are developed to cover particular content, and little 
importance is given to designing life skills programs based on sound teaching and learning principles (Nasheeda et al., 2018).

While life skills education programs are increasingly popular throughout the world of sport there remains a lack of information about the effectiveness of these programs in influencing long term, sustainable change for the participants (Nasheeda et al., 2018). There is a need to address the general lack of understanding of how life skills are learned and importantly the impact of life skills education on long term behavioural changes. It is apparent from the literature that there is a need to identify how knowledge is acquired and importantly retained through life skills education programs. Recently Debois, Ledon and Wylleman (2015) identified further research on athlete development at different domains of development including vocational development is needed.

\section{Life skills education in elite professional sport}

Life skills education is an increasingly popular phenomenon in adult sport settings, including elite sport. This is largely in response to the intense competitive pressures faced by elite athletes and the growing concern for individuals' health and well-being as they develop their career while trying to maintain a balance between life on and off the field (Manzini \& Gwandure, 2011; Pink, Saunders \& Stynes, 2015). In the Australian football context, research suggests that that allowing for the dual career development of footballers is important and may facilitate both player well-being and on-field performance (Pink et al., 2015). In addition, Pink et al., (2015) argued that football clubs have an ethical responsibility to support the development of dual careers to assist players find meaning in life beyond the sport. Dual career refers to "the challenge of combining a sporting career with studies or work, which remains a source of concern for most high-performance athletes" (Ryba et al. 2015, p. 125).

Life skills programs in professional sport settings are frequently associated with post sporting career options preparing the player for life after sport (Anderson, 2012; Hickey \& Kelly, 2008). The Positive Transitions Model for Sport Retirement (Meker, Stankovitch \& Kays, 2000; Stankovitch, Meeker \& Henderson, 2001), the Career Assistance Program for Athletes (Petitpas, Danish, McKelvain \& Murphy, 1992), the Strategies program (Coleman \& Barker, 1991), Going for Goal (Danish, 1997; Danish et al., 1992a, 1992b), Project Ithuseng (Draper, Forbes, Taylor \& Lambert, 2012), and the Life Development Intervention (Danish, Petipas \& Hale, 1993) are examples of these programs. Life skills programs in adult sport settings have been shown to improve the morale and performance of players (Manzini, 2012) in addition to developing inter- and intra-personal skills. However, there is a lack of research into the continuing effects of these programs beyond the sporting context.

This study looks specifically at Australian Footballers' experiences with the MAX 360 developed by the AFL Player's Association (AFLPA). MAX 360 offers individualised development action plans for both on and off the field. The program aims to simplify the tracking of a player's career and maximise individual growth in all areas of their life (Fillipou, 2014). Through conversations with player, club and industry the aim of the program is an off-field development action plan to direct players' development path towards industry in a meaningful and targeted manner (Fillipou, 2014). The MAX 360 program contains the following components: "Getting organised (implementing personal and professional self-management skills); Learning and Growth (engaging in appropriate educational or work experience programs); Financial Ownership (understanding basic financial management and future proofing); Personal Brand (identifying personal values and strengths and displaying these to others) and; Resilience and Thriving (building skills, knowledge and networks to become resilient, manage stress, and bounce back or know where to get help when needed)" (International Sports Care, 2019).

According to Martinek and Lee (2012), knowledge of whether the life skills transfer from the sport setting where the programs are implemented to other parts of the participants' life often remains disconnected from descriptions of the programs. This disconnection is often because transfer from the educational context in the sport settings is not an explicit concern of the program provider. This disconnect potentially affects the efficacy 
of the programs because the transfer from the program offered in the sport setting to life outside of football is not established (Gould \& Westfall, 2013).

We believe that the designers of sport based education programs should proceed with consideration of Danish, Taylor, and Fazio's (2003) recommended four teaching strategies for sport-based life skills programs focussed on transfer: 1. Instructors discuss how the life skills taught in the program link to sport performance; 2. Instructors provide participants with examples of how the life skills can be used in 'real life' settings; 3 . Instructors provide participants with opportunities to practice the life skills presented in their sport setting before then assisting in helping the participants create plans for using these skills in contexts outside the sports club setting; and 4. Instructors debrief with participants on their successful and unsuccessful life skills application in sport and life 'beyond the club'. In summary, life skills sport programs are capable of delivering positive outcomes when nurtured through a deliberately designed curriculum and purposeful teaching strategies (Camiré, Trudel \& Forneris, 2012; Teck Koh \& Camiré, 2015).

\section{Methodology}

The aim of this research was to explore the current life skills education programs offered by the AFL for elite footballers from the perspective of players who had been in the AFL system. The research questions were:

1) What are the opportunities for life skills development in elite Australian football?

2) To what extent is the life skills education knowledge transferrable beyond sport?

\section{Theoretical framework}

This was a qualitative research study from a life-history perspective, specifically, a stage in a life cycle approach. The life history approach is part of narrative inquiry, which provides an avenue for the telling of people's stories in order to understand their experiences within specific places or situations (Creswell, 2012; Goodson \& Sikes, 2001; Webster \& Mertova, 2007). Stage in a life cycle approaches (which can be captured through a life history approach) are underutilised in sport career transition research (Gordon \& Lavallee, 2012). Investigation of athlete experiences through stage in a life cycle approaches have been argued as being a useful addition to the current literature on sports transitions (Gordon \& Lavalee, 2012). Adopting a stage in a life cycle approach is one way that this paper adds value to the extant literature in sport life skills education.

The footballers who took part in this study chose to return to state based leagues rather than leave sport entirely, therefore, they have not yet fully transitioned into life after sport. This reflects Coakley's (2006) and Kelly and Hickey's (2008) assertion that retirement from sport can be viewed as a process rather than a single moment for many players.

\section{Participants}

Sample sizes in life history research tend to be relatively small to allow for the focus to be on the richness of the data (Goodson \& Sikes, 2001). Ten footballers aged between 20 and 31 years of age took part in this study. All of the footballers had played in the elite AFL competition and had returned to play in the sub-elite and semiprofessional South Australian National Football League (SANFL) state league competition following the end of their elite football careers. The footballers' careers in the AFL had lasted between 1 and 8 years. Two footballers had played over 100 games in the AFL, and three had not played a game in the elite competition while on an AFL team list.

All SANFL state league clubs were invited to participate in the research with three granting permission. Participants were sourced from those three clubs. The majority of the footballers $(n=9)$ were forced into 
retirement from the AFL competition through deselection (delisting) and 1 footballer chose to leave the AFL competition after contract negotiations did not conclude satisfactorily.

Following institutional ethics approval, participants were recruited purposefully (Patton, 2002) through the football managers in the SANFL clubs. The football managers were provided with an information letter detailing the study, which was then forwarded to the footballers in their clubs who had played in the national AFL competition. Following receipt of the information letter, participants were able to contact the researchers directly to indicate their interest in the study.

\section{Procedures}

Participants took part in a semi-structured interview which lasted between 28-60 minutes. The length of the interview was dependent on the comfort level of the participant with the topics and the level of self-reflection they felt was necessary (Polkinghorne, 1989). A semi-structured interview guide was utilised to ensure similar questions were asked of participants, however, the procedure also allowed for the interview to be directed by participants' responses (Patton, 1990). Each interview explored topics including what induction programs the footballers were involved in, what additional programs they completed throughout their career and what information they continue to use since retiring from elite level football.

\section{Analysis}

As qualitative research, thematic analysis of the data was appropriate. Thomas and Harden's (2008) three step inductive thematic analysis process was used to analyse the data. This involved the individual transcripts initially being coded line by line by two of the authors. Following the initial coding, the codes were grouped and refined until finally organised into descriptive themes. We then used a data synthesis approach to the analysis, to explore the themes within the context of the research questions (Thomas \& Harden, 2008).

\section{Trustworthiness}

Creswell and Miller (2000) encourage using several of the nine strategies they outline for establishing trustworthiness in qualitative research because "the emphasis of a study will vary depending on the project, the audience for whom we are writing, and the people available to provide an assessment of our project" (p. 129). This study incorporated peer review and an audit trail. As the focus in a stage of life approach to life history is on the richness of the data, thick, rich description was an important component in establishing the trustworthiness of this study. Through rich, thick descriptions the reader can gain a sense of what was experienced by participants, such that they might have experienced it themselves (Creswell \& Miller, 2000). While the focus of qualitative research is not necessarily to generalise for all people, rich descriptions can assist in determining the transferability of the findings to other settings (Creswell \& Miller, 2000).

To comply with Australian ethical guidelines, member checking was included in this study through participants being provided with a copy of their interview transcript and given two weeks to review and request changes if required. If no response was received within two weeks, the transcript was taken to be an accurate account of the interview. None of the participants requested any changes to their interview transcripts.

Peer review or peer debrief is the process of an external 'examiner' reviewing the research process and findings in order to provide critique and support for the researchers (Creswell \& Miller, 2000). According to Lincoln and Guba (1985), the peer reviewer can enhance the quality of the research by asking the difficult questions regarding methods and interpretations. In this study, this involved the primary researcher maintaining regular contact with an established expert in football operations management to discuss the process and findings. Smith 
and McGannon (2017) recommended this approach of utilising a critical friend during the reflective process rather than rely on inter-coder reliability.

\section{Results and discussion}

The data informing this paper forms part of a larger project on the transition experiences of elite Australian footballers who return to state-based leagues after their elite career has finished (Agnew, Marks, Henderson \& Woods, 2018). The scope of this paper is limited to the concepts relating to the education and life skill development of footballers. Two themes emerged from the life history approach consideration of the data relating to the education and life skills development of footballers; football related development and holistic development. Each of these themes had several sub-themes which are discussed in detail below.

\section{Football related development}

It was clear that the AFL clubs provided many development opportunities for the footballers. Some of these include the development of life skills such as managing their finances and cooking meals, while other opportunities were related to alternative career development which was directly related to preparing them for life after sport (Saunders \& Pink, 2014). However, the majority of guidance provided by the club related to the development of the men as footballers. Participants had access to nutritionists and fitness specialists to improve their performance, which had the potential to contribute to knowledge and skill development if retained beyond one's football career. However, it was also evident that the players football clubs may have competing interests between developing the men as footballers and developing them as people, which can be a barrier to life skill development opportunities and the guidance that is offered to footballers about life beyond football. These subthemes are explored below.

\section{Club guidance}

This study found that a shift in the importance of nutrition related knowledge appears to have occurred in the past two decades as most players in the current study reported ease of access to anything to do with nutrition. This is contrary to Ebert (2000) who found that Australian footballers were less educated about food composition and practical cooking skills. Everything was provided by the football club, from meals at the club to compulsory nutrition consultations, and cooking classes. However, this focus on dietary practices was mainly directed at new players (years 1-4).

While the data revealed that many players thought free access to nutrition advice was a good initiative the data also suggested some individuals misinterpreted the sports nutrition advice provided by the club Dietitian. Notably, the specific nutrient knowledge reportedly focussed on protein for muscle hypertrophy, with some information about carbohydrates and (physical) performance, but very little on foods and nutrients for health and well-being as stated by this participant:

So yeah I was on protein powders and sorts of- so a lot of protein powders with the mass-gain, plus then with the meals you'd eat. Just pretty much force yourself to eat, as much as you can in terms like with chicken and meat and brown rice and stuff like that, just to sort of really get your fuel levels up. (participant 8)

The focus on protein consumption may have been selective self-interest by the players, and more extensive nutrition advice may have been provided. However, players reported only short-term goals for nutrition management, with a focus on current desired body weight or body composition, rather than long-term health as explained by this footballer: 
No I just knew that eating protein and lots of it you actually get pretty big so that's all me and my house mate at the time- we were just 18 year olds and we were just trying to get big and we were eating heaps of food-carbohydrates and protein and just doing as many gym sessions as we could so that's all we were doing. (participant 2)

Adapting nutrient intake for current desired body weight or body composition is consistent with Jenner et al. (2018) who stated that particularly around body composition assessment times in the AFL season, footballers were not meeting the daily nutrient intake guidelines. Lohman et al. (2018) found that the majority of Australian footballers in their study over-consumed protein and under-consumed carbohydrate. The misunderstanding of nutrition advice revealed in our study is consistent with Lohman, Carr, and Condo (2018) and Trakman et al. (2018) who found that Australian footballers' sports nutrition knowledge was "poor".

Club guidance was particularly evident where football development was concerned. However, the requirement to participate in compulsory training or education and information sessions has the potential to lead to broader life skill development if the information is retained by the players. Many of the footballers in this research participated in the micro-credentialing (certificate short courses in a specified area) their football clubs were offering. Players repeatedly highlighted courses that were run through the football club, such as vocational education and training courses like certificate IV in fitness, certificates in coaching and business course management certificates. However, it was evident that the transferability of the life skills developed to areas outside of sport may not be recognised by the footballers. We are not suggesting that participating in the microcredentialing enables the players to get jobs or become job ready. Rather the footballers in this study appeared to perceive the micro-credentialing they had completed at the club to not be useful beyond sport. This was because the courses offered at the club were frequently not aligned to the post-sport career ambitions of the players.

Many players felt once they had left the AFL system they were educationally and socially 'behind' their high school peers. The participants talked about leaving the AFL system without qualifications which made it difficult to find employment. The footballers reported that they “would have been at Uni straight away if I didn't get drafted" and that because they were only able to study part time that football had "put me behind a little bit." Consistent with Saunders and Pink (2014), the demands of football and therefore not having enough time, were also argued to prevent footballers from pursuing subsequent career paths which has now inhibited their opportunities as stated by this participant:
I wanted to become, do a trade of my own and be mature aged, straight away you can sort of get looked past, because they can employ someone 2 years younger, 3 years younger for a lot less. So I think yeah, that was a-my biggest sort of - upset about was the fact that I've potentially missed out on having my own career as a carpenter or a plumber or electrician, just because I couldn't do the time required when I was on the [football] list. (participant 8)

The players in this study are still playing sub-elite football and so therefore can be considered to have not yet fully transitioned into life after sport. However, at this stage of their life many of their peers of a similar age have finished post-compulsory education and are in the process of establishing their professional work careers or have established a career in the trades. Although the footballers have had opportunities to establish what would be considered dual careers, they are not seeing it. What they appear to be seeing is the finish of one career and the need to start again to establish a completely alternative career.

Consistent with previous findings (Danish et al, 2008; Holt et al., 2008; Martinek \& Lee, 2012), the players in this study developed their life skills through the socialisation processes associated with being involved in football and they are still playing, therefore they do not seem to recognise the transferability of their life skills into a non-sporting context. While the sports clubs appear to place value on life skill education, from an athlete perspective there does not appear to be a transfer of knowledge beyond sport. 
It is important to note that the perception of their AFL career putting them "behind" in terms of a subsequent career is pertinent to footballers who have been delisted and have not had long AFL careers. Having focussed on achieving a career in the AFL for much of their youth and early adulthood, the delisted footballers in this study often have not had the time to complete qualifications and forge and alternative career path (Agnew et al., 2018). Participants in this research argued that if their careers had been longer it would not feel like such a sacrifice in terms of future career opportunities. However, now being "unprepared" for life after football led to the perception they were "behind", as highlighted by this participant:

I don't know just the way I sort of look at it now is I as soon as I was drafted I was way ahead of any of my friends in terms of yeah, setting myself up. The day I've been delisted it's sort of taken me 3 or 4 months now to realise that my friends are way far, way ahead of me. (participant 5)

\section{Competing interests}

It was evident that football clubs provided opportunities for the development of the footballers both on and off the field. However, it appeared that competing interests placed restrictions on what was permissible. This was particularly evident in terms of nutrition recommendations and off-field development. One of the constraints on football clubs is that they may be sponsored by nutrition focussed organisations. For example, the footballers in this research commented that because their club was sponsored by a particular company they were not permitted to "touch anything else" with regard to their nutrition supplementation. An all access report for a national education program on drugs (Bluestone Edge, 2013) argued some sports are concerned about the potential conflict of interest by having supplement companies sponsoring their high-performance programs. In this study, it appears the nutrition advice given to footballers may have been influenced by the need to maintain sponsor investment in the club.

While the majority of footballers perceived their clubs to be supportive of pursuing outside interests, in reality there were many restrictions placed on what they were allowed to do and what time they had available. Particularly in their first year at the club, while as new recruits they were required to do additional weights training sessions which meant attending the club on their rostered day off. The footballers agreed they were "happy" to do these sessions because they were there to play football, however, they also admitted the additional sessions could be a challenge to doing personal development activities, such as study:

In our first year it was sort of made compulsory for the first year players to come in and do extra weight sessions, which was, like I understand where they're coming from but again spending 7 days a week, 6-7 days a week at the club can be a bit much. (participant 8)

Restrictions were also placed on what outside interests could be pursued. The footballers highlighted their clubs were hesitant to allow them to follow an interest in trades which required extensive labour and had a high risk of injury. This might appear contrary to the research suggesting that having outside interests and therefore achieving more of a work life balance facilitates on field performance. It would seem to be in the clubs' best interests to promote footballers pursuing dual careers (Pink, et al., 2015). Nonetheless, given the restrictions placed on the footballers it is questionable whether the clubs really are promoting dual career possibilities or using outside interests as a tool to improve on field performance. We are not suggesting the clubs are not concerned with the holistic development of the players and some restrictions may be unavoidable. The challenge for clubs is how to work more meaningfully with players and their dual career development. Participants in this research stated they understood why these restrictions were put in place but felt this denied them the opportunity to pursue subsequent career paths they were interested in which meant they were not preparing for life after football. Typical of the responses is this quote:

I think yeah because the day off was a recovery day, so they didn't want you out working an 8 hour day slaving away on the tools. So yeah I can understand where they've come from there 
and it would have made life a lot harder, but as I said it sort of put you back a few steps. (participant 8)

\section{Holistic development}

The holistic development of footballers included mandatory induction programs when they first entered the AFL system as well as being involved in opportunities outside of football in order to prepare for life after football. The footballers recognised that having a good balance between football and outside interests was important but not knowing what they wanted to do along with the club restrictions on what they could do made finding the balance difficult. This supports Pink et al., (2015) who found that having a work/life balance was valued by players but that some declined to engage with dual careers because they needed time to consider their options. In the current study, there was a general sense that the mandatory induction programs were a component footballers needed to complete in order to 'tick the boxes' and begin their football career rather than being meaningful to them. However, it appears that that some nutrition knowledge is retained in life after football, therefore, there may be benefits of compulsory programs beyond the football field.

\section{Ticking the boxes}

It was clear through this research that the majority of footballers held little value for the compulsory induction programs ran by the AFL Players' Association (AFLPA) at the start of their careers. Consistent with Agnew et al. (2018), the footballers in this study stated they were required to attend programs on respect and responsibility (gender equality), drugs and alcohol, managing money, mental health issues and racial vilification. Common sentiments about these programs included comments such as "we did all of that, all the boring stuff with the AFLPA" and "each year players will have to do that and sign that off that they sat through it..." Players admitted they did not want to complete these programs and the common perception was that they could use the time to "switch off" even though many realised that the reason these programs are compulsory is because the concerns addressed are still issues in the AFL and broader society. The following comment summarises the perception from the majority of participants in this research about the compulsory programs:

I was never really keen on doing [it] - Ijust wanted to play footy, but you've got to do these things and you try and switch off that period of time and then you tick it off, but there's definitely a sense of just getting it done especially to a footballer but yeah. (participant 10)

Despite distributed learning being recommended over one off educational encounters to optimise long-term retention (Raman et al., 2010; Son \& Simon, 2012; Turner, 2006), players in this study argued having to complete them each year was repetitive and not necessary because the programs were based on "common sense". The footballers argued the program content had not changed during their time as a footballer, thus hearing the same information each time was not useful:

I reckon after the first one or two years it's the same program that they roll out and you've heard it before and you know what they're saying sort of thing; it's the same thing each year so you're not really learning anything new or-it's just rehashing the same information. (participant 1)

We suggest a consideration in the design and implementation of education programs where the aim of learning is for it to persist beyond the educational encounter is the distribution or the scheduling of study (Son and Simon 2012). From a life skills retention perspective, it would seem beneficial to incorporate distributed learning across the life-cycle of an AFL career. Distributed learning encounters, or spaced learning for long term retention have long been recommended, however, uninterrupted 'one off' educational encounters persist (Raman et al. 2010; Son and Simon 2012; Turner 2006). Distributed or spaced learning encounters repeated over a spaced period of time are advocated as this presentation of learning encounters improves retention of learning (Son and Simon 2012). 
However, rather than repeat the same learning format a variety of learning pedagogies is needed. Suggestions from players in this research for how to improve the program included making it more interactive for the players as opposed to sitting through a lecture style presentation and incorporating an online refresher course once the initial program is completed so that the footballers are not required to sit through the same sessions each year.

\section{Outside interests}

Part of the holistic development of footballers is allowing space for a balanced lifestyle. It was argued that the footballers who had outside interests and participated in the development opportunities off the field were the ones who had longer football careers. In addition, goals such as saving for a house or investing their money responsibly were thought to be ways of looking "after things off the field". The footballers were aware of the perception that their off-field situation had an influence on their on-field performance, (Pink et al., 2015), and therefore, it was important to ensure that things were going well off the field so they could play better. Not having an outside interest could lead to football being all-consuming which could be detrimental to performance as highlighted by this participant:

I think particularly at an AFL club you need to have something that's going to take your focus away from football because it can consume you and do your head in if you haven't got other interests and other focusses and that sort of stuff it can just suck you in and it can be really overwhelming because even on your days off if you are just sitting around and at home and you're just thinking about oh I've got to train tomorrow- what do I have to do now to get me up for training and all that sort of stuff...(participant 2)

Several of the men who had been part of the elite system for many years suggested that a shift in the culture of football clubs had occurred to allow for a more balanced lifestyle and preparation for life after football, as evidenced by this statement:

Yeah I definitely think, yeah I think the shift has happened like from the start of my career to the end of it-it was so much better in terms of support for what the guys were off the field and making sure they were doing something off the field and giving them the time to do it whereas in the first half of my career it was all about football and if you had any spare time make sure you're preparing of doing something extra and all that sort of thing. (participant 1)

The need to balance both football and outside interests was important to the players involved in this study. However, the perception was that football clubs would only be supportive of completing qualifications or developing alternative skills while they did not interfere with football performance. Participants suggested that if the pursuit of outside interests became a barrier to meeting the football demands or was perceived to be detrimental to performance it would not be tolerated. While space for the development of non-football related skills has increased it was recognised that young footballers in particular may not be concerned with their future and in some cases were unsure of what they wanted to do after their football careers were over. Therefore, deciding on what to do as an outside interest was difficult. Despite it appearing that for these players, the majority of the clubs encouraged or "border line force you to have something outside of football", the demands of football subordinated other demands (Hickey \& Kelly, 2007) and often left the footballers too tired to participate in anything else. For example, one player noted:

I guess as a youth you sort of- you're not so much looking at your distant future. But from where I was they really pushed you into getting involved in something outside of football so that you were prepared. Yeah [club name] being the club I was at was probably the most prepared in that sense, and really did push that. So that was good, but it's a struggle being so tired from football and that sort of stuff to get that third thing done whether it be study, or physical activity which is 
probably the last thing you want to do. So there is that sense of-from my experience that they're trying to get you to do something to prepare you. (participant 3)

Some elite AFL clubs did not appear to reinforce the need to have outside interests. This is consistent with previous findings (Saunders \& Pink, 2014) who found that outside interests were only perceived as valuable if the footballers enjoyed it, so forcing them to do something was not conducive to good practice. Some participants in this research argued that the clubs they were part of did not prevent footballers from doing 'something else' on their day off but they did not actively encourage it either. In addition, many clubs have rotating days off depending on the game day schedule which can be a limiting factor should players express a desire to study (Agnew et al., 2018). Several players argued that the driving force behind having outside interests often comes from the players themselves, and if enough players are interested the club will assist in organising a course to be completed at the club. As stated by this player, the club they were at would offer courses if they were asked for:

Yeah it's probably more driven by the players. I mean a couple of boys, or one or two blokes say that they want to do something, they might sort of throw it out there to a few others and if they get a good group together then the club will sort of help get that working but in terms of them just going out I guess on a limb and saying does anyone want to do PT, not really. I guess it sort of has to be cool with the first. (participant 5)

Similar to the study by Debois et al. (2015) it was apparent in this study that the players were afforded opportunities to consider post-football career development opportunities alongside their development as footballers. Our study shows that the players had the opportunity to combine their playing career with an academic or vocational pathway. However, the transferability of the opportunity into post-football career opportunities for the players was found to be questionable because the players failed to connect the relevance of the opportunities provided by the club to what they wanted to do post-football.

\section{Conclusion}

This study explored Australian footballers' experiences of the Max 360 program (Filippou, 2014) and what the players were able to take from the program and transfer into their dual career development and specifically, life after elite sport. The data suggested that for the players involved in this study there did not appear to be a transfer of knowledge beyond the program. What was retained from education programs provided in the elite sport setting was education related to their development as players.

The footballers' playing career is a significant stage in their lifecycle and has high importance placed on it (Agnew \& Drummond 2015), therefore, it is not surprising the knowledge related to football development is retained. However, we conclude the current format of life skill education (delivering content) that the players in this study were exposed to was not effective because the players failed to be able to make connections from the program to life outside of football. Therefore, the programs are unlikely to have any long-term benefit to player health and well-being during their post-elite football life.

Given this research focussed on a stage in a life-cycle approach, a longitudinal study which follows the same footballers into complete retirement from sport would be valuable to determine their adoption of the spectrum of life-skills acquired during their time at the elite AFL and subsequent SANFL. This would enable and understanding of what the value of their life skills education gained through sport is. It was determined through this study that the footballers do not recognise their football skills to be life skills as well and therefore transferable into non-sport contexts. We suggest that it is therefore important that life skill education programs delivered through sports clubs include specific information regarding the applicability of the sports skills into daily living. 


\section{Ethics approval and informed consent}

This research was approved by the Flinders University Social and Behavioral Research Ethics Committee, project number 7054 .

\section{Competing interests}

No potential conflict of interest for any of the authors to declare.

\section{Funding}

This work was supported by a Flinders University Establishment Research Grant.

\section{REFERENCES}

Agnew, D. \& Drummond, M. (2015). Always a footballer? The reconstruction of masculine identity following retirement from elite Australian football. Qualitative research in sport, exercise and health, 7(1), 68-87.

Agnew, D., Marks, A., Henderson, P. \& Woods, C. (2018). Deselection from elite Australian football as the catalyst for a return to sub-elite competitions: when elite players feel there is 'still more to give.'. Qualitative Research in Sport, Exercise and Health, 10(1), 117-136.

Anderson, D. (2012). A balanced approach to excellence: life-skill intervention and elite performance. Reflective Practice, 13(4), 609-620.

Atkinson, J.R., Boudville, A.I., Stanford, E.E., Lange, F.D. \& Anjou, M.D. (2014). Australian football league clinics; Promoting health, hygiene and trachoma elimination: the Northern territory expereince. Australian Journal of Primary Health, 20, 334-338.

Bluestone Edge. (2013). ACCESS ALL LEVELS: Review \& scope for a national education program on illicit \& performance enhancing drugs for sub-elite \& community level sport. Retrieved from https://www.ausport.gov.au/_data/assets/pdf_file/0006/436749/Bluestone_Edge_Access_All_Levels_Report_Oct13_FI NAL.pdf

Braun, V. \& Clarke, V. (2013). Successful qualitative research: A practical guide for beginners. London: Sage

Brunelle, J., Danish, S.J. \& Forneris, T. (2007). The impact of a sport-based life skill program on adolesecent prosocial values. Applied Developmental Science, 11(1), 43-55.

Camire, M. \& Trudel, P. (2013). Using high school football to promote life skills and student engagement: Perspectives from Canadian coaches and students. World Journal of Education, 3(3), 40-51.

Camire, M., Trudel, P. \& Forneris, T. (2012). Coaching And transferring life skills: Philosophies and strategies used by model high school coaches. The Sport Psychologist, 26(2), 243-260.

Coakley, S.C. (2006). A phenomenological exploration of the sport-career transition experiences that affect subjective well-being of former National Football League players. Retrieved from https://libres.uncg.edu/ir/uncg/f/umi-uncg1099.pdf.

Coleman, V.D. \& Barker, S.A. (1991). A model of acreer developemnt for student-athletes. Academic Athletic Journal, Spring, 33-40.

Creswell, J.W. \& Miller, D.L. (2000). Determining validity in qualitative inquiry. Theory into practice, 39 (3), $124-130$.

Creswell, J. (2012). Educational research: planning, conducting, and evaluating quantitative and qualitative research. 4 th ed. Boston: Pearson Education.

Danish, S.J. (1997). Going for the goal: A life skills program for adolescents. In G. Albee \& T. Gullota (Eds.), Primary prevention works (pp. 291-312). Thousand Oaks, CA: Sage.

Danish, S.J., Mash, J.M., Howard, C.W., Curl, S.J., Meyer, A.L., Owens, S., et al. (1992a). Going for the goal leader manual. Richmond VA: Department of Psychology, Virginia Commonwealth University.

Danish, S.J., Mash, J.M., Howard, C.W., Curl, S.J., Meyer, A.L., Owens, S., et al. (1992b). Going for the goal student activity manual. Richmond VA: Department of Psychology, Virginia Commonwealth University.

Danish, S.J., Petipas, A.J. \& Hale, B.D. (1993). Life development interventions for athletes: Life skills through sports. The Counseling Psychologist, 21, 352-385. 
Danish, S.J., Taylor, T.E. \& Fazio, R.J. (2003). Enhancing adolescent development through sports and leisure. In G. R. Adams \& M. D. Berznsley (Eds.), Blackwell Handbook Of Adolescence (pp. 92-108). Malden, MA: Blackwell Publishing.

Denzin, N.K. (1989). Interpretive interactionism. Newbury Park, CA: Sage.

Denzin, N.K. (2017). Critical qualitative inquiry. Qualitative inquiry, 23, 8-16.

Dinan Thompson, M., Sellwood, J. \& Carless, F. (2008). A kickstart to life: Australian football league as a medium for promoting lifeskills in cape york indigenous communities. The Australian Journal of Indigenous Education, 37(1), 152164.

Draper, C.E., Forbes, J., Taylor, G. \& Lambert, M.I. (2012). Empowering professional soccer players in South Africa: Evaluation of project Ithuseng. Internatioanl Journal of Sports Science \& Coaching, 7(3), 579-591.

Ebert, T.R. (2000). Nutrition for the Australian Rules football player. Journal of Science and Medicine in Sport 3(4), 369382.

Fillipou, M. (2014). What is Max 360? Retrieved from http://www.aflplayers.com.au/article/what-is-max360/

Goodson, I. \& Sikes, P. (2001). Life history research in educational settings: learning from lives, Buckingham, United Kingdom: Open University Press.

Gordon, S. \& Lavallee, D., (2012). Career transitions. In T. Morris \& P. Terry (Eds.), The new sport and exercise psychology companion (pp. 567-582). Morgantown, WV: Fitness Information Technology.

Gould, D. \& Westfall, S. (2013). Promoting life skills in children and youth: Applications to sport contexts. In A.R. Gomes, R. Resende \& A. Albuquerque (Eds.), Positive human functioning from a multidimensional perspective. Vol. 2: Promoting healthy lifestyles (pp. 53-77). Hauppauge, NY: Nova Publishing.

Harwood, C. (2008). Developmental consulting in a professional football academy:The 5Cs coaching efficacy program. The Sport Psychologist, 22(1), 109-133.

Hickey, C. \& Kelly, P. (2007, January). Education or regulation: managing behaviour change in the AFL. In AARE 2007: proceedings of the 2007 international educational research conference (pp. 1-16). Association for Active Educational Researchers.

Hickey, C. \& Kelly, P. (2008). Preparing to not be a footballer: higher education and professional sport. Sport, Education and Society, 13(4), 477-494.

Holt, N.L., Tamminen, K.A., Tink, L.N. \& Black, D.E. (2009). An interpretive analysis of life skills associated with sport participation. Qualitative Research in Sport and Exercise, 1(2), 160-175.

Holt, N.L., Tink, L.N., Mandigo, J.L. \& Fox, K.R. (2008). Do youth learn life skills through their involvement in high school sport? A case study. Canadian Journal of Education, 31(2), 281-304.

International Sports Care. (2019). The Life-Max 360 Program. Retrieved November 6, 2019, from http://www.isportscare.com/services/players-and-athletes/the-life-max-360-program.php

Jenner, S.L., Trakman, G., Coutts, A., Kempton, T., Ryan, S., Forsyth, A. \& Belski, R. (2018). Dietary intake of professional Australian football athletes surrounding body composition assessment. Journal of the International Society of Sports Nutrition, 15(1), 43.

Karpinski, C. (2012). Exporing the feasibility of an academic course that provides nutrition education to collegiate studentathletes. Journal of Nutrition Education and Behaviour, 44(3), 267-270.

Kelly, P. \& Hickey, C. (2008). The struggle for the body, mind and soul of AFL footballers. North Melbourne: Australian Scholarly.

Lincoln, Y.S. \& Guba, E.G. (1985). Naturalistic inquiry. Newbury Park, CA: Sage.

Lohman, R., Carr, A. \& Condo, D. (2018). Nutritional intake in Australian football players: sports nutrition knowledge, macronutrient and micronutrient intake. International Journal of Sport Nutrition and Exercise Metabolism, 0(0), 1-21.

Manzini, H. (2012). An investigation of perceptions of football players and officals on the provision of employee assiatance programs by football clubs in South Africa. Electronic Theses and Dissertations. Retrieved from http://wiredspace.wits.ac.za/handle/10539/11550

Manzini, H. \& Gwandure, C. (2011). The provision of employee assiatance programmes in South African football clubs: A case study. Journal of Social Sciences, 27(2), 75-83.

Martinek, T. \& Lee, O. (2012). From community gyms to classrooms: A framework for values-transfer in schools. Journal of Physical Education, Recreation \& Dance, 83(1), 33-51.

Meker, D.J., Stankovitch, C.E. \& Kays, T.M., (2000). Positive transitions for stusdent athletes: Life skills for trasnitions in sport, college \& career. Scottsdale, AZ: Holocombe-Hathaway. 
Nasheeda, A., Abdullah, H.B., Krauss, S.E. \& Ahmed, N.B. (2018). A narrative systematic review of life skills education: effectiveness, research gaps and priorities. International Journal of Adolescence and Youth. iFirst article, DOI: $10.1080 / 02673843.2018 .1479278$

National Health and Medical Research Council, 2015. The national statement on ethical conduct in human research, 2007. Canberra: The National Health and Medical Research Council, the Australian Research Council and the Australian Vice Chancellors' Committee.

Neesham, G. \& Garnham, A.P. (2012). Success story: Clontarf Foundation promotes education, life-skills and employment prospects through Australian Rules Football. British Journal of Sports Medicine, 46(13), 898-899.

Papacharisis, V., Goudas, M., Danish, S.J. \& Theodorakis, Y. (2005) The effectiveness of teaching a life skills program in a sport context, Journal Of Applied Sport Psychology, 17(3), 247-254.

Patton, M. (1990). Qualitative evaluation and research methods. Beverly Hills, CA: Sage Publications.

Patton, M. (2002). Qualitative evaluation and research methods. Beverly Hills, CA: Sage Publications.

Petitpas, A., Danish,S., McKelvain, R. \& Murphy, S. (1992). A career assiatance program for elite athletes. Journal of Counselling \& Development, 70, 383-386.

Petitpas, A.J., Van Raalte, J.L., Cornelius, A.E. \& Presbrey, J. (2004). A life skills development program for high school studet-athletes. The Journal of Primary Prevention, 24(3), 325-334.

Pink, M., Saunders, J. \& Stynes, J. (2015). Reconciling the maintenance of on-field success with off-field player development: A case study of a club culture within the Australian Football League. Psychology of Sport and Exercise, 21, 98-108.

Polkinghorne, D.E. (1989). Phenomenological research methods. In R.S. Valle., M. King \& S. Halling (Eds.), Existentialphenomenological perspectives in psychology: Exploring the breadth of human experience (pp. 41-60). Boston, MA: Springer.

Raman, M., Mclaughlin, K., Violato, C., Rostom, A., Allard, J. \& Coderre, S. (2010). Teaching in small portions dispersed over time enhances long-term knowledge retention. Medical Teacher, 32(3), 250-255.

Ryba, T.V., Stambulva, N.B., Ronkainen, N.J., Bundgaard, J. \& Selanne, H. (2015). Dual career pathways of transnational athletes. Psychology of Sport and Exercise, 21, 125-134.

Saunders, J. \& Pink, M. (2014). The relationship between player off-field engagement and on-field performance: final report. Virginia, Queensland: Australian Catholic University.

Smith, B. \& McGannon, K.R. (2017). Developing rigor in qualitative research: problems and opportunities within sport and exercise psychology. International review of sport and exercise psychology, 11(1), 1-21.

Son, L.K. \& Simon, D.A. (2012). Distributed learning: Data, metacognition, and educational implications. Educational Psychology Review, 24, 379-399.

Stankovitch, C.E., Meeker, D.J. \& Henderson, J.L. (2001). The positive transitions model for sport retirement. Journal of College Counselling, 4, 81-84.

Teck Koh, K. \& Camire, M. (2015). Strategies for the development of life skills and values through sort programs: Review and recommendations. In H.K. Leng \& N. Yang Hsu (Eds.), Emereging Trends and Innovation in Sports Marketing and Management in Asia (pp. 241-256). IGI Global.

Thomas, J. \& Harden, A. (2008). Methods for the thematic synthesis of qualitative research in systematic reviews. BMC medical research methodology, 8, 45-55.

Trakman, G.L., Forsyth, A., Middleton, K., Hoye, R., Jenner, S., Keenan, S. \& Belski, R. (2018). Australian football athletes lack awareness of current sport nutrition guidelines. International Journal of Sport Nutrition and Exercise Metabolism, 1-30. doi: https://doi.org/10.1123/ijsnem.2018-0002

Turner, E. (2006). Learning that lasts. Industrial And Commercial Training, 38(3), 137-142.

Webster, L. \& Mertova, P. (2007). Using narrative inquiry as a research method: an introduction to using critical event narrative analysis in research on learning and teaching. Abington: Routledge.

Weiss, M.R., Stuntz, C.P., Bhalla, J.A., Bolter, N.D. \& Price, M.S. (2013). 'more than a game': Impact of The First Tee life skills proramme on positive youth development: project introduction and Year 1 findings. Qualitative Research in Sport, Exercise and Health, 5(2), 214-244.

Whitley, M.A., Missy Wright, E. \& Gould, D. (2016). Coaches' perspectives on teaching life skills to underserved South African children and youth. International Journal of Sports Science and Coaching, 11(3), 312-326. 


\section{AUTHOR'S ADDRESS:}

Deborah Agnew

Flinders University

College of Education, Psychology and Social Work

GPO Box 2100

Adelaide, South Australia, Australia 5001

E-mail: deb.agnew@ flinders.edu.au

Received: 11 April 2019; Accepted: 6 November 2019 